УДК 347.77

DOI https://doi.org/10.32837/pyuv.v1i3(28).338

\author{
К.Д. Янішевська \\ кандидат юридичних наук, доцент, \\ старший викладач кафедри \\ кримінально-правових дисциплін та судочинства \\ Навчально-наукового інституту права \\ Сумського державного університету \\ О.Р.Тертичний \\ магістрант \\ Навчально-наукового інституту права \\ Сумського державного університету
}

\title{
ПРАВОВЕ РЕГУЛЮВАННЯ НАУКОВОГО ВІДКРИТТЯ ЯК ОБ'СКТА ІНТЕЛЕКТУАЛЬНОЇ ВЛАСНОСТІ
}

Одним із важливих напрямів розвитку інноваційної моделі інтелектуальної власності в нашій державі є захист об'єктів інтелектуальної власності, які саме в новітній час потребують законодавчої охорони й регулювання. Одним із таких специфічних об'єктів є наукове відкриття. Упровадження наукових відкриттів сприяє новим напрямам у розвитку окремих галузей науки, техніки, медицини, промисловості тощо. Безсумнівно, наукове відкриття має бути одним із головних чинників науково-технологічного прогресу в Україні, тому що новітні знання, які виникають у зв'язку з ним, не тільки удосконалюють наукову сферу, а й істотно впливають на розвиток економіки країни. На сьогодні, незважаючи на актуалізацію необхідності правової охорони наукових відкриттів, на жаль, вона не закріплена належним чином на законодавчому рівні.

Сьогодні бракує досліджень із даної тематики. Проте фрагментарно цю тему в її різних правових аспектах вивчали такі науковці, як: Є.А. Булат, В.Б. Харченко, А.В. Гончарова, Р.О. Денисова, О.В. Пічкур, Д.Р. Мієнко, М.I. Чешко.

Мета статті - дослідження і розкриття правової природи наукового відкриття як нетрадиційного об’єкта інтелектуальної власності, виявлення його особливостей.

На сьогодні проблематика захисту прав на наукові відкриття пов'язана передусім із тим, що в Україні й досі немає спеціального закону, який би врегулював майнові й особисті немайнові права суб'єктів права інтелектуальної власності на наукові відкриття.

Наукові відкриття нині охороняються нормами авторського права як науково-літературні твори, що неправильно. Таке явище не повною мірою забезпечує правову охорону даного об'єкта інтелектуальної власності. Однак правові засади охорони прав на наукові відкриття регулюються лише нормами ст. ст. 457-458 Цивільного кодексу України.
Дослідження наукових відкриттів як об'єктів інтелектуальної власності є досить актуальним, оскільки з першого погляду воно здається досить зрозумілим, але насправді породжує низку питань і дискусій як у сфері цивілістичної літератури, так і серед законодавців. Важливість також пов'язана із значенням явища наукового відкриття для всього людства, тому що всі наукові відкриття, представленні світу, докорінно щось змінюють у суспільній, економічній і політичній сферах діяльності.

Початком розвитку охорони наукових відкриттів можна вважати ухвалення постанови Ради Міністрів Союзу Радянських Соціалістичних Республік (далі - СРСР) від 14 березня 1947 р. № 525 «Про створення при Раді Міністрів СРСР Комітету з винаходів і відкриттів». Цією постановою фактично був створений радянський інститут із визнання і реєстрації наукових відкриттів. У цій системі найбільше значення приділялось науці, у результаті чого в цей період проводилось широке стимулювання максимального розкриття можливостей наявного наукового потенціалу та його зростання.

Водночас інститут реєстрації наукових відкриттів сприймався неоднозначно, мав своїх прихильників і опонентів, між якими свого часу розгорнулася гостра дискусія щодо доцільності його існування. Як відомо, висновок щодо доцільності існування інституту реєстрації наукових відкриттів був ухвалений на користь його опонентів $[1$, c. 8].

Нині стан питання щодо охорони наукових відкриттів в Україні є недосконалим. Причинами такого явища можуть бути: низька популярність такого об'єкта інтелектуальної власності, як наукові відкриття, безперешкодне використання його будь-ким і неефективний державний контроль.

На початку XXI ст. наука та досягнення $є$ важелем суспільного розвитку у провідних країнах світу. Науку за її суттю умовно поділяють на: 
фундаментальну, що спрямована на розкриття закономірностей і законів розвитку природи, які існують в об'єктивній реальності, та прикладну, що зорієнтована на вирішення передусім конкретного утилітарного завдання, зазвичай пов' язаного зі стимулюванням позитивних і подоланням негативних (кризових) процесів і явищ.

У ст. 1 Закону України «Про наукову і науково-технічнудіяльність» містятьсятаківизначення:

1) фундаментальні наукові дослідження - наукова теоретична та (або) експериментальна діяльність, спрямована на одержання нових знань про закономірності розвитку природи, суспільства, людини, їх взаємозв'язок;

2) прикладні наукові дослідження - наукова i науково-технічна діяльність, спрямована на одержання і використання знань для практичних цілей [2].

Учені вважають, що наукове відкриття є нетрадиційним об'єктом інтелектуальної власності.

У цивільному праві України існують різні класифікації щодо виділення інститутів права інтелектуальної власності. Зазвичай до таких інститутів відносять: інститут авторського права i суміжних прав, інститут промислової власності (патентного права та засобів індивідуалізації учасників цивільного обороту), інститут специфічних об’єктів.

Відповідно до Закону України «Про наукову і науково-технічну діяльність» від 26 листопада 2015 р. № 848-VIII, наукова діяльність - інтелектуальна творча діяльність, спрямована на одержання нових знань та (або) пошук шляхів їх застосування, основними видами якої є фундаментальні та прикладні наукові дослідження [2].

Відповідно до ст. 418 Цивільного кодексу України (далі - ЦК України), право інтелектуальної власності - це право особи на результат інтелектуальної, творчої діяльності або на інший об’єкт права інтелектуальної діяльності, визначений цим Кодексом та іншими законами [3].

Із цього випливає, що не будь-яка творча й інтелектуальна діяльність може визнаватись об’єктом інтелектуальної власності та підпадати під захист цивільного законодавства. Право інтелектуальної власності непорушне. Ніхто не може бути позбавлений прав інтелектуальної власності чи обмежений у їх використанні, окрім випадків, передбачених законом.

Відповідно до ст. 457 Цивільного кодексу України, науковим відкриттям є встановлення невідомих раніше, але об'єктивно існуючих закономірностей, властивостей і явищ матеріального світу, які вносять докорінні зміни в рівень наукового пізнання.

На нашу думку, поняття, визначене законодавцем, не є повноцінним, з одного боку, вказано сутність даної категорії, але не надано відповідних ознак і властивостей цього об’єкта інтелектуальної власності.

На відміну від більшості інших об'єктів, Цивільний кодекс України не визначає, хто є суб'єктом права на наукове відкриття. У ст. 458 лише згадано його як «автора» у зв'язку з визначенням основних прав на наукове відкриття [3], але водночас не охороняється Законом України «Про авторське право і суміжні права» [4].

Звертаючи увагу на те, що частіше за все авторами наукового відкриття будуть особи, що займаються саме науковими дослідженнями, доцільно вказати суб'єктів такої діяльності.

Так, відповідно до ст. 4 Закону України «Про наукову і науково-технічну діяльність», суб'єктами наукової та науково-технічної діяльності є: наукові працівники, науково-педагогічні працівники, аспіранти, ад'юнкти і докторанти, інші вчені, наукові установи, університети, академії, інститути, музеї, інші юридичні особи незалежно від форми власності, що мають відповідні наукові підрозділи, та громадські наукові організації в науковій і науково-технічній діяльності [2].

Отже, з вищевказаних положень суб'єкта права інтелектуальної власності на наукове відкриття можна визначити як особу, творчою працею якої утверджується те чи інше відкриття. Авторами наукового відкриття можуть бути лише фізичні особи, а також іноземні громадяни. Якщо ж наукове відкриття розроблене кількома особами, то виникає співавторство на даний об'єкт інтелектуальної власності.

Особисті немайнові права інтелектуальної власності належать творцеві об'єкта права інтелектуальної власності. Підтвердженням цього є положення Цивільного кодексу (далі - ЦК) України, згідно із ч. 1 ст. 438 якого особисті немайнові права належать автору. Також фізична особа не може відмовитися від особистих немайнових прав, а також не може бути позбавлена цих прав (ч. 3 ст. 269 ЦК України) [3]. Виходить, що наявність особистих немайнових прав інтелектуальної власності може бути безпосередньо пов' язана з фізичним існуванням матеріалізованого об'єкта.

Наукове відкриття вважається надбанням усього людства, саме тому, зважаючи на специфіку даного об'єкта, виключного права встановити на нього не можна. Ідеться про комплекс немайнових прав, які виникають в автора відкриття зі створенням. Автор має право лише на отримання диплома на нього й одноразової матеріальної винагороди.

Автори наукових відкриттів мають такі права: право на визнання його творцем (автором) наукового відкриття; право надати науковому відкриттю своє ім'я або спеціальну назву; право перешкоджати будь-якому посяганню на право інтелектуальної власності, здатному завдати шко- 
ди його честі чи репутації; інші особисті немайнові права інтелектуальної власності, встановлені законом.

Серед прав основними є право авторства - право вважатися першовідкривачем певних знань, право на ім'я - право надати відкриттю своє ім'я або спеціальну назву.

На нашу думку, особисті немайнові права автора наукового відкриття - це абсолютні, невідчужувані, суб'єктивні права фізичних і юридичних осіб, які безстроково охороняються державою та виникають із моменту створення невідомих раніше закономірностей, властивостей і явищ.

Після створення наукового відкриття, об'єкта інтелектуальної власності існує необхідність оформлення права на такий об'єкт, а саме забезпечити правову охорону такого відкриття.

Охорона державою прав суб'єктів інтелектуальної власності сприяє розвитку науково-дослідної діяльності, збільшенню кількості літературних творів, винаходів, промислових зразків тощо. Саме це сприяє розвитку технічного процесу та підвищенню культури громадян.

Зміст наукового відкриття становлять знання про те, що цей об'єкт наукового відкриття (закономірність, властивість, явище) існує. Наукове відкриття, яке проявляється у вирішенні завдань пізнання, полягає у виявленні суттєвих, необхідних, таких, що повторюються, зв'язків у матеріальному світі, а не у встановленні якихось раніше не відомих матеріальних об'єктів. 3 моменту оприлюднення вони стають суспільним надбанням і можуть вільно використовуватись кожною особою, яка в цьому зацікавлена [5, с. 136].

Охоронним документом, що засвідчує право інтелектуальної власності на наукове відкриття, $\mathrm{e}$ диплом на наукове відкриття та його державна реєстрація. Диплом визнає результат наукової творчості науковим відкриттям, визначає авторство особи, що зробила наукове відкриття та встановлює пріоритет наукового відкриття.

Згідно із ч. 2 ст. 458 ЦК України, правова охорона наукового відкриття здійснюється в порядку, встановленому законом, однак ЦК України не містить норм, що закріплюють особливості набуття правової охорони цього нетрадиційного об'єкта права інтелектуальної власності [3].

Нині не передбачено також детальної процедури державної реєстрації набуття прав власності на наукове відкриття. В Україні діє громадська організація Асоціація авторів наукових відкриттів України, яка реєструє наукові відкриття, але без їх належної державної експертизи. Для авторів об'єктів, які можуть бути визнані державою науковими відкриттями, сьогодні актуальною $€$ публікація як факт першості автора даного відкриття (для закріплення пріоритету) з наступною реєстрацією прав на науковий результат як на об'єкт авторського правf.

Також потребує вдосконалення процедура видачі диплома на наукове відкриття. Такі положення було б доцільно також розмістити у відповідному спеціалізованому Законі «Про охорону прав на наукові відкриття».

Якщо автор захоче й матиме змогу описати процес і результати свого відкриття, він може викласти його положення у книжці, статті, доповіді на конференції тощо, але відповідний усний чи письмовий твір охоронятиметься вже як об'єкт авторського права.

На нашу думку, експертизу заявлених наукових відкриттів має проводити створений відповідно до зазначеної мети відділ Національної академії наук (далі - НАН) України. НАН України, маючи загальнодержавний статус, є вищою державною науковою організацією України, яка організовує і здійснює фундаментальні та прикладні наукові дослідження.

Порівняно зі звичайною публікацією своїх наукових доробків, більш доцільніше й ефективніше було б упровадження Відкритого державного реєстру наукових відкриттів, який був би доступний кожному для перегляду. Такий Реєстр збирав би в одному місці всі визнані відповідно до попередньо проведеної експертизи, зареєстровані наукові відкриття. Дана пропозиція підтверджується позитивним досвідом Радянського Союзу, де діяв Державний реєстр відкриттів СРСР. Це був систематизований звід документованої інформації про наукові відкриття, зареєстровані у СРСР із 1957 по 1991 pp.

Так, B.I. Дирда зазначає, що державна система реєстрації відкриттів важлива ще й тому, що вона створює унікальні можливості для об'єктивної оцінки наукової діяльності вчених, вимагає від них уваги щодо детального аналізу результатів своїх робіт. Найчастіше для доказу відкриття використовуються результати, отримані в суміжних науках, у яких через сформовані досвід, традиції, термінологію ті самі закономірності (або тільки окрема частина їх) можуть трактуватися по-різномy [6, с. 19].

Отже, охорона і відповідне законодавче регулювання цих об'єктів дозволить удосконалити і підвищити рівень наукових досягнень і зацікавленості суспільства в подальших дослідженнях. Упровадження правової охорони такого об'єкта інтелектуальної власності, як наукові відкриття, стане гарантією розвитку нових технологій і запобігання правопорушенням у цій сфері. 


\section{Jimepamypa}

1. Булат Є.А. Наукове відкриття як об'єкт цивільних правовідносин : автореф. дис. ... канд. юрид. наук: 12.00.03. Київ, 2010. 17 с.

2. Про наукову i науково-технічну діяльність : Закон України від 26 листопада 2015 р. № 848-VIII. Відомості Верховної Ради України. 2016. № 3. С. 25

3. Цивільний кодекс України від 16 січня 2003 р. № 435-IV. Відомості Верховної Ради України. 2003. № № 40-44. Ст. 356 .

4. Про авторське право і суміжні права : Закон України від 23 грудня 1993 р. № 3792-XII. Відомості Верховної Ради України. 1994. № 13. Ст. 64.

5. Коросташова I.M. Нетрадиційні об'єкти інтелектуальної власності: питання правової охорони. Інтелектуальна власність : збірник праць / за ред. P.C. Кіріна ; М-во освіти і науки України ; Нац. гірн. ун-т. 2014. С. 127-138.

6. Дирда В.И. Некоторые проблемы взаимосвязи философии и науки в контексте научных открытий в механике разрушения. Геотехнічна механіка: міжвідомчий збірник наукових праиь Iнституту ге отехнічної механіки ілені М.С. Полякова. Дніпропетровськ, 2014. Вип. 116. 219 с.

\section{Анотація}

Янішевська К. Д., Тертичний О.Р. Правове регулювання наукового відкриття як об'єкта інтелектуальної власності. - Стаття.

У статті аналізуються питання вдосконалення правового регулювання наукового відкриття. У результаті дослідження специфіки даного інституту з'ясовано, що наукове відкриття є нетрадиційним об'єктом права інтелектуальної власності, оскільки йому властиві як загальні ознаки, так і особливі. Зважаючи на його фундаментальний характер, наукове відкриття може мати будь-яку форму та є процесом пізнання об'єктивної дійсності, що нехарактерно для будь-яких інших об'єктів правової охорони.

Визначено основні права авторства на наукові відкриття, а саме: право вважатися першовідкривачем певних знань та право на ім'я, а також право надати відкриттю своє ім'я або спеціальну назву. Право інтелектуальної власності є непорушним і належить володільцю, ніхто не може бути позбавлений його. Права інтелектуальної власності можуть бути обмежені лише в предбачених законом випадках.

Визначено суб'єкта права інтелектуальної власності на наукове відкриття й авторське поняття особистих немайнових прав автора наукового відкриття як об'єкта інтелектуальної власності.

Доведено, що українське законодавство щодо правової охорони наукових відкриттів потребує вдосконалення через ухвалення відповідного закону, що підтверджується визнанням Всесвітньою організацією інтелектуальної власності наукового відкриття як результату творчої діяльності, який потребує відповідного правового регулювання.

Вбачається необхідність у розробленні й ухваленні Закону України «Про охорону прав на наукові відкриття», який би врегулював такі важливі питання, як: процедура державної реєстрації набуття прав власності на наукове відкриття та видачі диплома; правове регу- лювання експертизи наукових відкриттів, метою якої $€$ перевірка заявленого об'єкта на відповідність усім умовам; охорона права пріоритетності; впровадження Відкритого державного реєстру наукових відкриттів; закріплення пільг за авторами наукових відкриттів.

Зроблено висновок, що охорона i відповідне законодавче регулювання наукового відкриття дозволить удосконалити і підвищити рівень наукових досягнень і зацікавленості суспільства в подальших дослідженнях.

Ключові слова: інтелектуальна власність, правове регулювання, наукове відкриття, особисті немайнові права, правова охорона.

\section{Summary}

Yanishevska K. D., Tertychnyi O. R. Legal regulation of scientific discovery as an intellectual property object. - Article.

The article analyzes the issue of improving the legal regulation of scientific discovery. Investigating the specifics of this institute, it has been found that scientific discovery is an unconventional object of intellectual property rights, since it has both common features and special features. Given its fundamental nature, a scientific discovery can take any form and is a process of cognition of objective reality, which is not typical of any other objects of legal protection.

The basic authorship rights to scientific discoveries are defined, namely: the right to be considered the discoverer of certain knowledge and the right to a name, as well as the right to provide a discovery with its own name or special name. The intellectual property right is inviolable and belongs to the owner; no one can be deprived of it. Restriction of intellectual property rights can occur only in cases provided by law.

The subject of intellectual property rights for a scientific discovery and the author's concept of personal non-property rights for a scientific discovery as an object of intellectual property is determined.

It is proved that the Ukrainian legislation regarding the legal protection of scientific discoveries needs to be improved by adopting a corresponding law, which is confirmed by the recognition by the World Intellectual Property Organization of a scientific discovery as a result of creative activity that requires appropriate legal regulation.

It is necessary to develop and adopt the Law of Ukraine On the Protection of Rights to Scientific Discoveries, which would resolve such important issues as the procedure for state registration of ownership of a scientific discovery and the issuance of a diploma; legal regulation of the examination of scientific discoveries, the purpose of which is to verify the claimed object for compliance with all conditions; protection of priority rights; implementation of the Open State Register of Scientific Discoveries; consolidation of benefits for the authors of scientific discoveries.

It is concluded that the protection and appropriate legislative regulation of scientific discovery will improve and increase the level of scientific achievements and public interest in further research.

Key words: intellectual property, legal regulation, scientific discovery, personal non-property rights, legal protection. 